\title{
RYZYKO ZAWODOWE W PRACY FIZJOTERAPEUTY W OCENIE STUDENTÓW
}

\section{OCCUPATIONAL HAZARD IN THE PROFESSION OF PHYSIOTHERAPISTS IN THE ASSESSMENT OF STUDENTS}

\author{
Sebastian Nieścioruk ${ }^{1(\mathrm{~A}, \mathrm{~B}, \mathrm{C}, \mathrm{D}, \mathrm{E}, \mathrm{F}, \mathrm{G})}$, Elżbieta Rutkowska ${ }^{1(\mathrm{~A}, \mathrm{~B}, \mathrm{C}, \mathrm{D}, \mathrm{E}, \mathrm{F}, \mathrm{G})}$ \\ ${ }^{1}$ Państwowa Szkoła Wyższa im. Papieża Jana Pawła II w Białej Podlaskiej
}

Nieścioruk, S., Rutkowska, E. (2018). Ryzyko zawodowe w pracy fizjoterapeuty w ocenie studentów. Rozprawy Społeczne, 12(3), 73-78. https://doi.org/10.29316/rs.2018.27

Wkład autorów:

A. Zaplanowanie badań

B. Zebranie danych

C. Dane - analiza i statystyki

D. Interpretacja danych

E. Przygotowanie artykułu

F. Wyszukiwanie i analiza

literatury

G. Zebranie funduszy
Tabele: 1

Ryciny: 0

Literatura: 22

Otrzymano: lipiec 2017

Zaakceptowano: sierpień 2017

\begin{abstract}
Streszczenie
Wstęp. Efekty kształcenia na studiach o profilu praktycznym przewidują przygotowanie studentów i absolwentów do wykonywania wszystkich standardowych czynności zawodowych. Równie ważnym elementem tego przygotowania jest świadomość ryzyka i zagrożeń własnego zdrowia osób, które ten zawód wykonują. Stanowi ona podstawę działań profilaktycznych służących ochronie zdrowia określonej grupy profesjonalistów. W kontekście najnowszych normalizacji prawnych zawodu oraz studiów fizjoterapii warto zwrócić uwagę na bezpieczeństwo pracy i ochronę zdrowia przedstawicieli tego zawodu medycznego.

Materiał i metody. W niniejszym doniesieniu zaprezentowano sumaryczny wynik studenckiego projektu semestralnego w zakresie definiowania czynników ryzyka w zawodzie fizjoterapeuty. Studenci magisterskich studiów fizjoterapii $(n=22)$ wykorzystali do tego zadania wzór pierwszej strony Karty Charakterystyk Zagrożeń Zawodowych, rekomendowanej przez właściwą agendę Organizacji Narodów Zjednoczonych.

Wyniki. Analiza pojedynczych projektów studenckich wskazuje na wysoki poziom świadomości ryzyka zawodowego w takich obszarach jak: niektóre czynniki fizyczne w pracowni fizykoterapii, zagrożenie epidemiologiczne $\mathrm{w}$ bezpośrednim kontakcie z pacjentem oraz relacje międzyludzkie w zespołach terapeutycznych.

Wnioski. Praktyczne studia fizjoterapii powinny w większym stopniu przygotowywać studentów do bezpiecznej pracy; wzmocnienia wymaga też przygotowanie do pracy w zespołach tera-
\end{abstract} peutycznych.

Słowa kluczowe: fizjoterapia, ryzyko zawodowe, projekt studencki

\section{Summary}

Introduction. Learning outcomes in academic education with prophylactic profile envisage preparation of students and graduates for all standard professional activities. An equally important element of this preparation is the awareness of the risks and threats to the health of people who perform this profession. It is the basis of preventive measures protecting the health of a specific group of professionals. In the context of the latest legal normalization of the profession and course of studies in the field of physiotherapy, it is worth paying attention to the occupational safety and health protection of the representatives of this medical profession.

Material and methods. This report presents the total result of a one-semester-long student project in the area of defining risk factors in the physiotherapists' profession. Students of master's physiotherapy courses $(n=22)$ used the model of the first page of the Occupational Hazard Card for this task, recommended by the relevant United Nations agency.

Results. Analysis of individual student projects indicates a high level of occupational riskawareness in such areas as: some physical factors in the physiotherapeutic surgery, epidemiological threat in direct contact with the patient and interpersonal relationships in therapeutic teams.

Conclusions. Practical physiotherapy studies should prepare students for performing work safely to a greater extent; preparation for work in therapeutic teams should be enhanced as well.

Keywords: physiotherapy, occupational risk, student project

\footnotetext{
Adres korespondencyjny: Sebastian Nieścioruk, Państwowa Szkoła Wyższa im. Papieża Jana Pawła II w Białej Podlaskiej, Hrud 123A, 21-500, Biała Podlaska, e-mail: sebek007c@wp.pl,tel.: 507587857 


\section{Wstęp}

Po wielu latach społecznych dyskusji zawód fizjoterapeuty został ustawowo uregulowany w Polsce (Ustawa z dnia 25 września 2015 roku o zawodzie fizjoterapeuty). Ustawa precyzyjnie określiła zasady i prawo wykonywania zawodu fizjoterapeuty, system kształcenia podstawowego i ustawicznego oraz zakres odpowiedzialności zawodowej. Zamknięcie procesu legislacji dotyczącej tego zawodu medycznego dało umocowanie do wszelkich dalszych działań, mocujących sytuację zawodową fizjoterapeutów w Polsce. Do takich działań należy między innymi powołanie samorządu zawodowego w postaci Krajowej Izby Fizjoterapeutów o określonych kompetencjach w zakresie sprawowania opieki i kontroli jakości pracy tej grupy pracowników ochrony zdrowia.

Zakres obowiązków zawodowych i przewidywane stanowiska pracy dla fizjoterapeutów - poza w/w ustawą-precyzują ponadto takie dokumenty jak: Europejska Deklaracja Standardów w Fizjoterapii (Europejska Deklaracja Standardów w Fizjoterapii z dnia 4 czerwca 2003 roku) oraz Krajowy Standard Kwalifikacji Zawodowych (Krajowy Standard Kwalifikacji Zawodowych Fizjoterapeuta (9223903). Wszystkie te dokumenty pozwalają przewidzieć zakres pracy i zadania zawodowe (wymagające kwalifikacji podstawowych i specjalistycznych) oraz umiejętności ogólnozawodowe i ponadzawodowe, określone umiejscowieniem zawodu w sektorach gospodarki: w tym przypadku w szeroko rozumianej ochronie zdrowia. Ich osią są: wiedza i praktyka fizjoterapeutyczna (m.in. w zakresie kinezyterapii, fizykoterapii, masażu, usprawniania funkcjonalnego, adaptowanej aktywności fizycznej, sportu osób niepełnosprawnych itd.). Zajmowane stanowisko i przypisywany im zasięg kwalifikacji zawodowych oraz przewidywanych dla fizjoterapeuty stanowisk pracy i czynności zawodowych zależny jest od poziomu wykształcenia, stażu pracy, doświadczenia, kompetencji społecznych itd. Według Krajowego Standardu Kwalifikacji zawodowych fizjoterapeuta może wykonywać czynności zawodowe:

- pod kontrola przełożonego i nie ponosić za nią odpowiedzialności (pierwszy poziom);

- samodzielnie-ale pod nadzorem kierownika -i z odpowiedzialnością karną za błędy (drugi poziom);

- samodzielnie, złożone i nietypowe czynności zawodowe; kierowanie kilkuosobowym zespołem fizjoterapeutów - z odpowiedzialnością za pracę wykonywaną osobiście i przez podległych pracowników (trzeci poziom);

- fizjoterapeuta na tym poziomie kieruje zespołami liczącymi do kilkunastu osób - często podzielonych na podzespoły. Specjalistyczne zadania zawodowe mają charakter złożony (dotyczą nie tylko fizjoterapii, ale także techniki i organizacji pracy). Wymagają osobistej samodzielności i odpowiedzialności (czwarty poziom);

- praca na tym poziomie (poziom piąty) przewidziana jest do fizjoterapeutów o najwyższych kompetencjach zawodowych, w pełni samodzielnych, kierujących organizacją pracy zespołów, podejmujących strategiczne decyzje, ważne dla całokształtu procesu fizjoterapii. Taka osoba odpowiada także za pracę i rozwój zawodowy podległych pracowników (Krajowy Standard Kwalifikacji Zawodowych Fizjoterapeuta (9223903).

Powyższa analiza czynności i stanowisk pracy na drodze awansu zawodowego fizjoterapeuty pozwala przewidywać ryzyko związane z wykonywaniem każdej z nich. Zasady bezpieczeństwa i higieny pracy, które obowiązują fizjoterapeutów w placówkach służby zdrowia na podstawie przepisów ogólnych (Rozporządzenie Ministra Pracy i Polityki Socjalnej z dnia 26 września 1997roku) nie wyczerpują jednak wszystkich sytuacji oraz specyficznych obowiązków i zadań tej grupy zawodowej na wszystkich poziomach kwalifikacji zawodowych (Kujawa, Kaczocha, 2014, Marcinkowski, 2003). Szerzej opisywano je w opracowaniach dotyczących techników fizjoterapii (Karczewski, Rączkowski, Ziętkiewicz, 2002) lub analizowano jedynie wybrany czynnik ryzyka, związany ze sposobem wykonywania niektórych procedur (Nowotny-Czupryna, Nowotny, Brzęk, 2003). Wobec niedawnej regulacji prawnej i autonomii zawodu fizjoterapeuty warto byłoby ocenić wszystkie aspekty jego zadań zawodowych i precyzyjnie określić zagrożenia w środowisku pracy, które mogą być powodem urazu lub pogorszenia stanu zdrowia samych fizjoterapeutów. W dalszym etapie należy określić, jakie działania należy podjąć w celu ochrony zdrowia fizjoterapeutów.

Interesującym wzorem do realizacji takiego zadania może być Karta Charakterystyk Zagrożeń Zawodowych. Karty powstały one w ramach międzynarodowego projektu i koordynowanego od 1998 roku przez Międzynarodowe Centrum Informacji o Bezpieczeństwie i Higienie Pracy przy agendzie Organizacji Narodów Zjednoczonych (Międzynarodowa Organizacja Pracy- International Labour Organization) wraz z instytucjami podrzędnymi (Łastowiecka-Moras, Bugajska, 2013). Integralnym elementem opracowania takiego dokumentu jest precyzyjna charakterystyka zawodu, wynikająca $\mathrm{z}$ jego regulacji prawnych i standardowych czynności (Bugajska, 2003).

Omawiany wyżej projekt zakłada, że Karta Charakterystyk Zagrożeń Zawodowych składa się z czterech stron, na których opisane są:

- str. 1. zdefiniowane zagrożenia zdrowia pracownika podczas wykonywania rutynowych czynności

- str. 2. szczególne i usystematyzowane czynniki ryzyka (czasem też możliwe i skutki)

- str. 3. wskazania środków i działań profilaktycznych 
- str.4. wynikające z powyższych - szczególnie istotne zalecenia dla specjalistów i służb bezpieczeństwa pracy (Bugajska, 2000).

Dotychczas opracowano 87 szczegółowych i kompletnych (czterostronicowych) ocen ryzyka dla wybranych zawodów. Są one ogólnie dostępne na stronie internetowej Centralnego Instytutu Ochrony Pracy - Państwowego Instytutu Badawczego (Międzynarodowe Karty Zagrożeń Zawodowych). Nie opracowano jednak szczegółowej oceny ryzyka zawodowego dla możliwych stanowisk pracy fizjoterapeuty na każdym z poziomów kompetencji.

Celem niniejszego doniesienia jest prezentacja syntetycznego wyniku prac studentów fizjoterapii nad czynnikami ryzyka w ich przyszłym zawodzie, opracowanych według wzoru pierwszej strony Karty Charakterystyk Zagrożeń Zawodowych.

\section{Materiał i metody}

Dla opracowania projektu pierwszej strony Karty Charakterystyk Zagrożeń Zawodowych w zawodzie fizjoterapeuty posłużono się metodą analizy źródeł pisanych, pojedynczych kart zagrożeń, opracowanych przez 22 studentów magisterskich studiów fizjoterapii Państwowej Szkoły Wyższej im. Papieża Jana Pawła II w Białej Podlaskiej. Karty były opracowane w ramach przedmiotu „Ergonomia pracy" w roku akademickim 2016/17. Identyfikację czynników ryzyka poprzedzono starannymi studiami wyżej wspomnianych dokumentów, charakteryzujących stanowiska pracy, kompetencje oraz umiejętności zawodowe, używany sprzęt i na- rzędzia wykorzystywane w procedurach fizjoterapeutycznych. Przedyskutowano także obserwacje oraz osobiste doświadczenia studentów, zdobyte w trakcie obowiązkowych praktyk programowych z kinezyterapii, fizykoterapii, masażu oraz fizjoterapii klinicznej w różnych zakładach opieki zdrowotnej.

Określając zagrożenia zawodowe w pracy fizjoterapeuty, studenci zapoznali się także z tymi, które zostały zidentyfikowane w pokrewnych zawodach medycznych, takich jak: lekarz, pielęgniarka, pielęgniarka operacyjna, pielęgniarka środowiskowa, ratownik medyczny, nauczyciel wychowania fizycznego. Dla tych zawodów istnieją kompletne Karty Charakterystyk Zagrożeń Zawodowych (Międzynarodowe Karty Charakterystyki Zagrożeń Zawodowych).

\section{Wyniki}

Zgodnie z przyjętym schematem karty zidentyfikowane zagrożenia zawodowe zakwalifikowano do pięciu grup:

- czynniki mogące powodować wypadki,

- czynniki fizyczne,

- czynniki chemiczne i pyły,

- czynniki biologiczne,

- czynniki ergonomiczne, psychospołeczne i związane z organizacją pracy (Łastowiecka -Moras, Bugajska, 2013).

Syntetyczny obraz zagrożeń zawodowych, zidentyfikowanych przez studentów przedstawiono w tabeli 1.

Tabela 1. Projekt Karty Charakterystyki Zagrożeń Zawodowych - fizjoterapeuta

\begin{tabular}{|c|c|c|}
\hline $\begin{array}{l}\text { Czynniki } \\
\text { środowiska pracy }\end{array}$ & Zidentyfikowane przez studentów & $\begin{array}{c}\text { Liczba (\%) stu- } \\
\text { dentów, którzy } \\
\text { zidentyfikowali } \\
\text { zagrożenia }\end{array}$ \\
\hline \multirow{8}{*}{$\begin{array}{l}\text { Czynniki mogące } \\
\text { powodować } \\
\text { wypadki }\end{array}$} & - śliska podłoga, niestabilne podłoże - upadki & $21(95 \%)$ \\
\hline & - pacjent - jego ryzykowne zachowania & $18(82 \%)$ \\
\hline & - urazy wynikające z obsługi urządzeń i sprzętu rehabilitacyjnego & $11(77 \%)$ \\
\hline & $\begin{array}{l}\text { - prąd elektryczny - ryzyko porażenia podczas obsługi urządzeń elektrycz- } \\
\text { nych }\end{array}$ & $14(64 \%)$ \\
\hline & - lekceważenie przepisów BHP przez pracownika & $14(64 \%)$ \\
\hline & $\begin{array}{l}\text { - duże obciążenia mechaniczne (dźwiganie, pionizacja, przenoszenie) } \\
\text { pacjenta }\end{array}$ & $12(55 \%)$ \\
\hline & \begin{tabular}{|l|} 
- wysokie temperatury - ryzyko oparzeń podczas \\
wykony wania zabiegów termoterapii
\end{tabular} & $10(46 \%)$ \\
\hline & $\begin{array}{l}\text { - ostre przedmioty - np. zużyte ampułki leków, szkło z lamp sollux - ryzyko } \\
\text { zranień }\end{array}$ & $7(32 \%)$ \\
\hline \multirow{7}{*}{ Czynniki fizyczne } & - pole magnetyczne & $22(100 \%)$ \\
\hline & - promieniowanie laserowe & $21(95 \%)$ \\
\hline & - prąd elektryczny & $20(91 \%)$ \\
\hline & - promieniowanie UV & $12(55 \%)$ \\
\hline & - promieniowanie IR & $11(50 \%)$ \\
\hline & - promieniowanie RTG & $7(32 \%)$ \\
\hline & - wibracje & $3(14 \%)$ \\
\hline
\end{tabular}




\begin{tabular}{|c|c|c|}
\hline \begin{tabular}{|c|} 
Czynniki \\
środowiska pracy
\end{tabular} & Zidentyfikowane przez studentów & $\begin{array}{c}\text { Liczba (\%) stu- } \\
\text { dentów, którzy } \\
\text { zidentyfikowali } \\
\text { zagrożenia }\end{array}$ \\
\hline \multirow{4}{*}{$\begin{array}{l}\text { Czynniki chemiczne } \\
\text { i pyły }\end{array}$} & - leki (w fizykoterapii i masażu) & $20(91 \%)$ \\
\hline & - środki antyseptyczne, detergenty & $20(91 \%)$ \\
\hline & - środki wspomagające masaż (np. talk) & $20(90 \%)$ \\
\hline & - lateks (rękawice) & $14(64 \%)$ \\
\hline \multirow{2}{*}{$\begin{array}{l}\text { Czynniki } \\
\text { biologiczne }\end{array}$} & $\begin{array}{l}\text { - płyny ustrojowe, wydzieliny, wydaliny pacjenta: } \\
\text { w tym bakterie i wirusy (HIV, WZW) }\end{array}$ & $20(91 \%)$ \\
\hline & $\begin{array}{l}\text { - inne mikroorganizmy chorobotwórcze (pomieszczenia, sprzęt, personel } \\
\text {-nosiciele) }\end{array}$ & $14(64 \%)$ \\
\hline \multirow{10}{*}{$\begin{array}{c}\text { Czynniki } \\
\text { ergonomiczne, } \\
\text { psychospołeczne } \\
\text { i związane } \\
\text { z organizacją pracy }\end{array}$} & - relacje międzyludzkie w zespole & $21(95 \%)$ \\
\hline & - presja wywierana przez pracodawcę (w tym mobbing) & $20(91 \%)$ \\
\hline & - presja wywierana przez rodziny pacjentów & $20(91 \%)$ \\
\hline & - agresywne zachowania pacjentów & $20(91 \%)$ \\
\hline & - obciążenie psychiczne pracą z osobami ciężko i nieuleczalnie chorymi & $19(86 \%)$ \\
\hline & - odpowiedzialność karna i zawodowa za błędy w sztuce & $18(82 \%)$ \\
\hline & - przeciążenie mechaniczne narządu ruchu (dźwiganie pacjentów i sprzętu) & $12(55 \%)$ \\
\hline & - wymuszona pozycja ciała na niektórych stanowiskach & $10(46 \%)$ \\
\hline & - wypalenie zawodowe & $16(73 \%)$ \\
\hline & $\begin{array}{l}\text { - rutyna i powtarzalność wybranych technik terapeutycznych; jednostronne } \\
\text { obciążenia narządu ruchu }\end{array}$ & 8 (37\%) \\
\hline
\end{tabular}

Powyższe informacje pokazują, w jaki sposób studenci fizjoterapii oceniają poziom ryzyka zawodowego i które z okoliczności pracy wskazują najczęściej jako potencjalne zagrożenie własnego zdrowia.

\section{Dyskusja}

W związku z unifikacją kształcenia przed- i podyplomowego oraz stanowisk i kompetencji w pracy fizjoterapeuty warto zwrócić również szczególną uwagę na jego bezpieczeństwo pracy. Ustawowo określona autonomia upoważnia do prac nad odrębną Kartą Charakterystyk Zagrożeń Zawodowych.

Opisana powyżej próba identyfikacji i gradacji czynników ryzyka przez studentów studiów II stopnia w zakresie fizjoterapii stanowi zaledwie pierwszy etap prac nad ochroną zdrowia tej grupy zawodowej. Kolejne etapy powinny doprowadzić - zgodnie z założeniem projektu kart - do przewidzenia skutków zdrowotnych ekspozycji na czynniki ryzyka, a finalnie: opracowania wskazówek dla działań zapobiegawczych odpowiednich służb bezpieczeństwa pracy (Szczygielska 2009, Bugajska, 2002). Zadanie to jest istotne, ze względu na powierzchowny i niewystarczający poziom wiedzy o czynnikach ryzyka pracy różnych grup zawodowych, przy czym pracownicy służby zdrowia nie prezentują istotnie większego zasobu wiedzy w tym zakresie! (Kozajda, Zielińska-Jankiewicz, Szadkowska-Stańczyk, 2005). Niezadowalający poziom wiedzy o ryzyku zagrożenia zdrowia oraz dużą nieznajomość zasad bezpieczeństwa pracy w zawodzie fizjoterapeuty wykazali także studenci ostatnich lat studiów przygotowujących do tego zawodu w trzech polskich uczelniach (Popko, 2010).

Prezentowane przez nas wyniki prac studentów nad różnymi grupami czynników stanowiących zagrożenie zdrowia $w$ ich przyszłej pracy (Tab.1) pokazują, że poziom świadomości ryzyka zawodowego jest największy w zakresie czynników fizycznych, na których ekspozycję są narażeni w pracowni fizykoterapii. Przy czym najczęściej wymieniane są: „pole magnetyczne” (100\% wskazań) oraz „promieniowanie laserowe” i „prąd elektryczny”. Mniejszym ryzykiem zdrowotnym dla terapeuty - zdaniem wielu studentów - obarczone są światłolecznicze zabiegi fizykalne, co może skutkować lekceważeniem środków ostrożności podczas ich aplikacji pacjentom.

W opinii prawie wszystkich studentów wypełniających swoje karty istotnym wyzwaniem mogą być czynniki psychospołeczne środowiska pracy: konflikty między samymi członkami zespołów rehabilitacyjnych, relacje z przełożonymi (w tym ryzyko mobbingu), presja czasu pracy. Autorzy kart uważają także, że znacznym obciążeniem dla nich są sytuacje, które powstają w relacjach terapeutycznych $\mathrm{z}$ pacjentem (możliwość ryzykownych zachowań, presji i agresji pacjenta, ale też konieczność towarzyszenia osobom ciężko i nieuleczalnie chorym). Wielu studentów (82\%) ma świadomość ryzyka błędu w sztuce - i związanej z tym odpowiedzialności karnej a prawie $2 / 3$ badanych uważa, że fizjoterapeuta może być obciążony zespołem wypalenia zawodowego. To znany problem przedstawicieli zawodów medycznych, który coraz częściej opisywany jest wśród fizjoterapeutów (Kowalska, 2011, Wrzesińska, Rasmus, Wicherska, Krukowska, 2016). 
Analizujac wskazania prawie wszystkich studentów (91\%) można zauważyć, że respondenci mają świadomość ryzyka wynikającego z użycia środków farmakologicznych wspomagających i ułatwiających masaż, stosowanych do jonto-, i fonoforez $\mathrm{w}$ terapiach. Ryzyko na podobnym poziomie może wynikać także powszechnie stosowanych środków dezynfekcyjnych.

We wskazaniach około połowy (46-55\%) z grupy autorów kart ważnym czynnikiem ryzyka zawodowego $\mathrm{w}$ pracy fizjoterapeuty są przeciążenia mechaniczne narządu ruchu, związane z koniecznością dźwigania pacjentów, wymuszoną pozycją ciała i jednostronnym obciążeniem rutynowymi technikami ruchu podczas kinezyterapii. Wydaje się, że studenci niedostatecznie szacuja ryzyko zdrowotne tego aspektu swojej przyszłej pracy w świetle doniesień o powszechnym zjawisku przeciążeń układu mięśniowo-szkieletowego pracowników tej grupy zawodowej (Mikołajewska, 2013, Rozenfeld, Ribak, Danziger, Tsamir, Carmeli, 2010, Grooten, Wernstedt, Campo., 2011). Wysoko skalkulowane jest natomiast ryzyko upadku i urazu podczas czynności zawodowych fizjoterapeutów, co w zestawieniu dość powszechnie wymienianym $(64 \%$ wskazań) ryzykiem lekceważenia przepisów BHP - może to ryzyko znacząco podnosić.

Podobnie nieoszacowanym ryzykiem (pomijanym w pracach studentów) jest ekspozycja na mikroorganizmy chorobotwórcze niepochodzące od pacjenta - takie jak: pomieszczenia, sprzęt rehabilitacyjny czy współpracownicy, którzy mogą stanowić wtórne źródło zakażenia. W zaledwie ponad co drugiej (64\%) z wypełnionych kart zidentyfikowano ten czynnik ryzyka. Natomiast prawie wszyscy studenci (91\%) uznają za ryzykowny kontakt z płynami ustrojowymi pacjenta. W dwu kartach takiego wskazania nie było. Prawdopodobnie ci studenci uznali, że w fizjoterapii nie występują procedury medyczne przebiegające z naruszeniem ciągłości skóry, zatem ryzyko bezpośredniego zakażenia nie występuje.
Przytoczone powyżej analizy prac studentów, pozwoliły pośrednio ocenić ich stan wiedzy o ryzyku zawodowym, ale też określić stopień wrażliwości na różne grupy czynników środowiska pracy. Brak dotychczas opracowanej Karty Charakterystyk Zagrożenia Zawodowego dla fizjoterapeuty i jednocześnie niedawno określona prawnie tożsamość zawodowa uzasadniają dalsze prace także nad strategią ochrony zdrowia tej grupy zawodowej (Świątkowska, 2010). Opisane tu praktyczne ćwiczenie studentów i jego wynik mogą inicjować takie prace.

\section{Wnioski}

- Wiedza i umiejętności studentów w zakresie ochrony ich zdrowia w czasie praktyk zawodowych oraz w przyszłej pracy to istotny efekt kształcenia na studiach o profilu praktycznym, wymagające większej uwagi od nauczycieli akademickich i opiekunów praktyk zawodowych.

- Studencki projekt Karty Charakterystyk Zagrożenia Zawodowego może być inspirującym i użytecznym ćwiczeniem, które sprawdza wiedzę i wskazuje nieoszacowane czynniki ryzyka wymagające większej uwagi w kształceniu zawodowym studentów.

- W projektach omawianej grupy studentów magisterskich studiów fizjoterapii wykazano zbyt częste pomijanie we wskazaniach ryzyka zakażeń w środowisku pracy niezwiązanych $\mathrm{z}$ bezpośrednim kontaktem $\mathrm{z}$ chorym oraz wysoką świadomość ryzyka podczas aplikacji niektórych zabiegów fizykalnych.

- Znacznym ryzykiem zawodowym zdaniem dużej grupy studentów mogą być psychospołeczne czynniki środowiska pracy - co powinno skłaniać do większej humanizacji studiów fizjoterapii.

\section{Literatura:}

1. Bugajska, J. (2000). Karty Charakterystyki Zawodów jako źródło informacji dla celów profilaktyki zdrowotnej. Medycyna Pracy, 51(6), 551-561.

2. Europejska Deklaracja Standardów w Fizjoterapii - wersja ostateczna, przyjęta na Nadzwyczajnym Zgromadzeniu Ogólnym w dn. 4. czerwca 2003 roku w Barcelonie

3. Grooten, W.J., Wernstedt, P., Campo, M. (2011). Work-related musculoskeletal disorders in female Swedish physical therapists with more than 15 years of job experience: Prevalence and associations with work exposures. Physiother. Theory Pract, 27(3), 213-222. https://doi.org/10.3109/09593985.2010.481323

4. Karczewski, J.T., Rączkowski, B., Ziętkiewicz, K. (2002). Ocena ryzyka zawodowego na stanowisku Technik Fizjoterapii. Gdańsk: Wyd. ODDK.

5. Kowalska, J. (2011). Wypalenie zawodowe wśród polskich fizjoterapeutów/Professional burnout in Polish physiotherapists. Advances in Rehabilitation, 25(3), 43-51.https://doi.org/10.2478/rehab-2013-0014

6. Kozajda, A., Zielińska-Jankiewicz, K., Szadkowska-Stańczyk, I. (2005). Wiedza wybranych grup zawodowych o rodzajach czynników biologicznych obecnych w środowisku pracy oraz o sposobach ochrony przed ich szkodliwym wpływem. Część II. Medycyna Pracy, 57(3), 205-211.

7. Krajowy Standard Kwalifikacji Zawodowych. Fizjoterapeuta (9223903). (2006). Specjaliści. Warszawa: Min. Pracy i Polityki Społ. 
8. Kujawa, A., Kaczocha, M. (2014). BHP w służbie zdrowia. Szkolenia, ryzyko zawodowe, czynniki szkodliwe, wymagania dla pomieszczeń, wypadki i choroby zawodowe. Warszawa: Wyd. C.H. Beck.

9. Łastowiecka-Moras, E., Bugajska, J. (2013). Karty charakterystyki zagrożeń zawodowych jako użyteczne narzędzie pracy dla służby. $B H P, 1,28-30$.

10. Marcinkowski, J.T., (2003). Higiena, profilaktyka i organizacja w zawodach medycznych. Wyd. Lek. PZWL, Warszawa

11. Międzynarodowe Karty Charakterystyki Zagrożeń Zawodowych. Pobrane z: www.ciop.pl

12. Międzynarodowe Karty Charakterystyki Zagrożeń Zawodowych. Pobrane z www.ciop.pl

13. Mikołajewska, E. (2013). Urazy mięśniowo-szkieletowe związane z pracą u fizjoterapeutów. Medycyna Pracy, 64(5), 681-687.

14. Nowotny-Czupryna, 0., Nowotny, J., Brzęk, A. (2003). Ergonomiczne aspekty pracy fizjoterapeuty. Fizjoterapia Polska, 3(4), 287-395.

15. Passier, L., McPhail, S. (2011). Work related musculoskeletal disorders amongst therapists in physically demanding roles: Qualitative analysis of risk factors and strategies for prevention. BMC Musculoskelet. Disord., 12, 24-27. https://doi.org/10.1186/1471-2474-12-24

16. Popko, B. (2010). Znajomość zasad bezpieczeństwa pracy w zawodzie fizjoterapeuty studentów ostatnich lat studiów. Praca magisterska. Zamość: Wyższa Szkoła Zarządzania i Administracji.

17. Rozenfeld, V., Ribak, J., Danziger, J., Tsamir, J., Carmeli, E. (2010). Prevalence, risk factors and preventive strategies in work-related musculoskeletal disorders among Israeli physical therapists. Physiother. Res. Int., 15(3), 176-184. https://doi.org/10.1002/pri.440

18. Rozporządzenie Ministra Pracy i Polityki Socjalnej z dnia 26 września 1997 w sprawie ogólnych przepisów bezpieczeństwa i higieny pracy.

19. Szczygielska, A. (2009). Promowanie bezpieczeństwa pracy w przedsiębiorstwach-na przykładzie Forum Liderów Bezpiecznej Pracy. Bezpieczeństwo Pracy: nauka i praktyka, 4, 26-29.

20. Świątkowska, B. (2010). Zagrożenia zawodowe pracowników opieki zdrowotnej: Co wiemy i co możemy zrobić. Prob. Hig. Epidemiol, 91(4), 522-529.

21. Ustawa z dnia 25 września 2015 r. o zawodzie fizjoterapeuty, Dz.U.2015 poz.1994.

22. Wrzesińska, M., Rasmus, P., Wicherska, K., Krukowska, J. (2016). Wypalenie zawodowe a zmienne demograficzne i psychospołeczne u aktywnych zawodowo fizjoterapeutów. Zdrowie Publiczne i Zarzq̨dzanie, 13(3), 295-301. 